\title{
Risk assessment of water and mud inrush in a tunnel in Chongqing based on analytic hierarchy process
}

\author{
Yong Wang, ${ }^{1, *}$ \\ ${ }^{1}$ The First Municipal Design Institute, Chongqing Architectural Design Institute Co.,LTD, 40015 Chongqing, China
}

\begin{abstract}
Water and mud inrush is one of the typical geological hazards during tunnel construction in karst area. In weight of water or mud inrush risks of karst tunnels are studied and the index system for water and mud inrush risk evaluation is established based on analytic hierarchy process. The analysis shows that geological structure, formation lithology and groundwater level are the main control ingredients of water or mud inrush risk; geographic and geomorphic conditions, attitude of rock formation are the minor significant factors; surrounding rock mass classification, rainfall are the least important elements. Aiming at a tunnel in Chongqing, combining with the actual geological situation of the tunnel site, the evaluation model is used to evaluate the risk of water and mud inrush in each section, which provides a certain theoretical basis for the prevention and control of water and mud inrush disaster during the tunnel construction.
\end{abstract}

\section{Introduction}

With the promotion of the strategy of "Western Development" and the construction of the Belt and Road Initiative, the Tunnel construction in China is gradually transferring to the western mountainous and karst areas with extremely complex terrain and geological conditions. It also presents the development trend of "large buried depth, long tunnel line, high stress, strong karst, high water pressure, complex structure, frequent disasters", and water and mud inrush disasters are becoming more and more serious. The water and mud inrush of tunnels in karst strata has always been considered as a worldwide problem. Once the disaster occurs, the tunnel will be submerged, the construction will be interrupted, and the heavy casualties and economic losses will be caused. And even some projects will be forced to stop or change lines ${ }^{[1]}$.

Accurate evaluation and prediction of the risk of water and mud inrush in tunnel is an effective method to prevent water and mud inrush disaster and reduce its impact on tunnel construction. How to accurately evaluate the risk of water inrush in tunnel design and construction stage has gradually become one of the key technical problems of tunnel construction in karst area ${ }^{[2-6]}$. At home and abroad, many scholars have done a lot of research on the risk analysis and application of water and mud inrush in karst tunnels in recent years. Mao Bangyan ${ }^{[7]}$ and others put forward the risk staging system of water and mud inrush in tunnels; Han Xingrui ${ }^{[8,9]}$ puts forward an expert evaluation system for karst water gushing in tunnels; Li Shucai ${ }^{[2-6]}$ and others have continuously improved the analytic hierarchy process (AHP) and applied it to the risk assessment of water inrush in different projects, and achieved good results. Zhang Qingsong ${ }^{[10]}$ and others have carried out the research on the theory and method of water inrush risk assessment of high-risk karst tunnels, and established the quantitative assessment method of water inrush risk and the four-color disaster warning mechanism; Kuang Xing ${ }^{[11]}$ and others established a geological disaster system for karst water inrush during tunnel construction in karst areas, and used a fuzzy comprehensive evaluation model to evaluate the risk of water inrush and mud inrush disasters in karst tunnels. In addition to using empirical models for evaluation, some progress has been made in using machine learning models, such as BP neural network model $^{[12]}$ to evaluate the risk of water and mud inrush in karst tunnels.

Analytic hierarchy process (AHP) is a simple and practical decision-making method, which can make the decision-making process hierarchical and quantitative according to certain rules. It is a decision-making method for multiple schemes or objectives. At present, the AHP is widely used in the risk assessment of water and mud inrush in karst tunnels, and has achieved good results ${ }^{[3-6,13-}$ 17]. A Tunnel in Chongqing is a deep and extra long mountain tunnel. The complex engineering geological and hydrogeological environmental conditions of the tunnel site are extremely easy to cause geological disasters such as water and mud inrush, which profoundly affects the safety of the construction and use of the tunnel. Therefore, the prevention and control of water and mud inrush is one of the important problems to be solved in the process of tunnel construction. It is the key to accurately evaluate the risk of water and mud inrush in each section of tunnel. Based on the analytic hierarchy process (AHP), this paper will choose appropriate evaluation indexes to evaluate the risk of water and mud inrush in the tunnel, so as to better prevent and control the water and mud inrush disaster in the tunnel and ensure the safety of the tunnel.

\footnotetext{
*Corresponding author: 851537298@qq.com
} 


\section{Establishment of evaluation index system for water and mud inrush risk of tunnel in karst area}

\subsection{Selection of risk influencing factors}

According to the basic geological characteristics of the tunnel site and the existing disaster-causing factors, combined with the research results of experts and scholars, we selected the formation lithology, geological structure, geographic and geomorphic conditions, groundwater level, attitude of rock formation, the level of surrounding rock, rainfall for seven evaluation factors, and divided the risk levels (levels are divided into I - IV, including I for the minimum risk, IV for the highest risk), and established an index system for risk evaluation of water and mud inrush of the tunnel in karst area.

\subsubsection{Geological structure}

Geological structural conditions not only control the migration and enrichment process of groundwater, but also determine the channel type, smoothness and water source strength of water gushing in tunnel area. When the fault structure connects the surface water, water rich cavity, underground river or high pressure aquifer with the tunnel, large-scale water gushing or water inrush disasters are usually formed ${ }^{[18]}$. Geological structure includes fault structure, fold structure and monoclinic structure. Due to the formation reasons of fault fracture zone, there are many kinds of strata lithology, geological structure development, serious rock weathering, broken rock mass, abundant groundwater supply, and complex geological conditions. After tunnel excavation, the underground hydraulic path is easy to change, and water and mud inrush are prone to occur under the joint action of in-situ stress and groundwater. In the fold structure, the rock mass in the syncline core is subject to horizontal compression, the fractures are relatively developed, the integrity and strength of the rock mass are poor, and the rock strata on both sides incline to the core, which easily makes the groundwater gather in the core, resulting in the relatively developed karst in the syncline core area. The rock mass in the core of the anticline is affected by horizontal rip, the fracture develops more and the integrity of rock mass is poor, which is convenient for the infiltration of surface water and underground water, so it is beneficial to the development of karst to some extent. In the water bearing rock group of monoclinic stratum, the difference of karst development degree is significant due to the influence of rock thickness and rock inclination. The steeper the rock inclination is, the smaller the catchment area exposed on the surface is, and the smaller the probability and scale of water inrush during tunnel crossing is. According to whether there are any unfavorable geological structures such as hidden rivers, water-filled mud-filled cavities, water-conducting faults, karst pipeline nearby the tunnel, $\mathrm{Xu}$ Zhenhao and others divided it into four grades according to the disaster causing strength and weakness:
Table1. Grade division of unfavorable geology

\begin{tabular}{|c|c|c|}
\hline $\begin{array}{l}\text { The grade } \\
\text { of disaster } \\
\text { causing }\end{array}$ & definition & $\begin{array}{c}\text { The } \\
\text { level } \\
\text { of } \\
\text { risk }\end{array}$ \\
\hline $\begin{array}{l}\text { Strong } \\
\text { disaster } \\
\text { causing }\end{array}$ & $\begin{array}{l}\text { There are spme large water-conducting } \\
\text { structures above the floor near the } \\
\text { tunnel, or some large pressurized } \\
\text { water-conducting structures below the } \\
\text { floor near the tunnel }\end{array}$ & I \\
\hline $\begin{array}{l}\text { Medium } \\
\text { disaster } \\
\text { causing }\end{array}$ & $\begin{array}{c}\text { There are some medium water- } \\
\text { conducting structures above the floor } \\
\text { near the tunnel, or some medium } \\
\text { pressurized water-conducting } \\
\text { structures below the floor near the } \\
\text { tunnel }\end{array}$ & II \\
\hline $\begin{array}{l}\text { Weak } \\
\text { disaster } \\
\text { causing }\end{array}$ & $\begin{array}{c}\text { There are some small water- } \\
\text { conducting structures above the floor } \\
\text { near the tunnel, or some } 1 \text { large } \\
\text { pressurized water-conducting } \\
\text { structures below the floor near the } \\
\text { tunnel }\end{array}$ & III \\
\hline $\begin{array}{l}\text { No disaster } \\
\text { causing }\end{array}$ & $\begin{array}{l}\text { There is no adverse geological } \\
\text { phenomenon that can cause water } \\
\text { inrush near the tunnel }\end{array}$ & IV \\
\hline
\end{tabular}

\subsubsection{Formation lithology}

The soluble rock stratum is the place where the groundwater is stored and transported. The chemical and mineral composition of the rock is closely related to the solubility of the rock. The differentiation caused by the difference of chemical composition and structure of soluble rock is the material basis of karst development, resulting in different enrichment space of groundwater, which determines the intensity and scale of water filling in the tunnel ${ }^{[18]}$. According to the solubility of stratigraphic lithology, the documents [3-4] divides it into four levels: strong, medium, weak and non-soluble rock. See Table 2 for the specific division.

Table2. Grade division of formation lithology for water inrush

\begin{tabular}{|c|c|c|}
\hline $\begin{array}{c}\text { The grade of } \\
\text { soluble rock }\end{array}$ & Rock types & $\begin{array}{c}\text { The } \\
\text { level } \\
\text { of } \\
\text { risk }\end{array}$ \\
\hline $\begin{array}{c}\text { strong soluble } \\
\text { rock }\end{array}$ & $\begin{array}{c}\text { thick - medium thick stratified pure } \\
\text { limestone, ancient siliceous } \\
\text { cemented dolomite, Carbonaceous } \\
\text { and asphaltic limestone }\end{array}$ & $\mathrm{I}$ \\
\hline
\end{tabular}




\begin{tabular}{|c|c|c|}
\hline $\begin{array}{c}\text { medium } \\
\text { soluble rock }\end{array}$ & $\begin{array}{c}\text { thick - medium thick marble, thick - } \\
\text { medium thick argillaceous } \\
\text { limestone, thick - medium thick } \\
\text { dolomite }\end{array}$ & II \\
\hline $\begin{array}{c}\text { weak soluble } \\
\text { rock }\end{array}$ & $\begin{array}{c}\text { thin marble, thin argillaceous } \\
\text { limestone and thin dolomite }\end{array}$ & III \\
\hline $\begin{array}{c}\text { non-soluble } \\
\text { rock }\end{array}$ & $\begin{array}{c}\text { Non-soluble rocks are generally } \\
\text { considered as reliable relative } \\
\text { impermeable and non-karst layers in } \\
\text { the area of carbonate rocks }\end{array}$ & IV \\
\hline
\end{tabular}

\subsubsection{Groundwater level}

Groundwater is the material basis and power source of karst water inrush ${ }^{[3-4]}$. The karst hydrodynamic vertical zoning can be divided into: vadose zone or vertical circulation zone, seasonal variation zone, saturated zone or horizontal circulation zone and siphon circulation zone. The vadose zone is located above the phreatic surface, and the surface water moves vertically downward through fissures. The karst forms are mainly funnel, sinkhole and shaft; In the seasonal variation zone, the groundwater movement alternates periodically with seasonal changes. The very active groundwater activities lead to the most developed karst in this zone, often forming large complex karst caves, underground rivers, underground lakes and so on. Similar to the seasonal variation zone, the groundwater activity in the shallow saturated zone is more intense, and karst development is more intense. Groundwater activities in deep saturated zone and subzones are gentle, but most of them are pressurized, and also have the risk of water and mud inrush disaster. Li Liping ${ }^{[3-4]}$ took the height difference $\mathrm{h}$ between the groundwater level and the tunnel floor as the factor determining the risk degree of water inrush, as shown in Table 3:

Table3. Grade division of groundwater table

\begin{tabular}{|c|c|c|}
\hline $\begin{array}{c}\text { The } \\
\text { range of } \\
\text { h }\end{array}$ & definition & $\begin{array}{c}\text { The } \\
\text { level } \\
\text { of } \\
\text { risk }\end{array}$ \\
\hline $\mathrm{h} \geq 60 \mathrm{~m}$ & $\begin{array}{c}\text { If karst water is exposed, the } \\
\text { instantaneous water inrush is large } \\
\text { and fast, which often causes heavy } \\
\text { casualties and property losses }\end{array}$ & I \\
\hline $\begin{array}{c}30 \mathrm{~m} \leq \mathrm{h} \\
<60 \mathrm{~m}\end{array}$ & Medium disaster causing & II \\
\hline $0 \mathrm{~m} \leq \mathrm{h}$ \\
$<30 \mathrm{~m}$ & $\begin{array}{c}\text { The seepage instability or overall } \\
\text { extrusion process of karst fillings } \\
\text { takes a long time and the disaster } \\
\text { causing ability is weak }\end{array}$ & III \\
\hline $\mathrm{h}<0 \mathrm{~m}$ & No risk of water and mud inrush & IV \\
\hline
\end{tabular}

\subsubsection{Geographic and geomorphic conditions}

Trough valley, karst depression, precipitation funnel, sinkhole and other surface karst forms are the main connecting channels of underground karst system, surface karst system and atmospheric precipitation, and the combined confluence capacity of different surface karst forms is obviously different ${ }^{[5]}$. The negative landform such as trough, sinkhole and precipitation funnel almost penetrates the surface water into the ground and has strong water collecting capacity, while the open low valley or slope land has weak water collecting capacity ${ }^{[18]}$. Yang Yanna $^{[18]}$ proposed that three methods can be used for quantitative evaluation of topography and geomorphology, that is, according to the surface precipitation infiltration conditions, according to the influence of surface karst morphology combination on the confluence intensity, and according to the slope gradient of surface precipitation infiltration conditions. According to the catchment capacity and karst development degree of the terrain, $\mathrm{Xu}$ Zhenhao ${ }^{[3-4]}$ and others divided the negative terrain into four levels, as shown in Table 4:

Table4. Grade division of groundwater table

\begin{tabular}{|c|c|c|}
\hline Classification & $\begin{array}{c}\text { Characteristics of Geographic and } \\
\text { geomorphic }\end{array}$ & $\begin{array}{c}\text { The } \\
\text { level } \\
\text { of } \\
\text { risk }\end{array}$ \\
\hline $\begin{array}{c}\text { Large negative } \\
\text { terrain }\end{array}$ & $\begin{array}{c}\text { It has strong water collecting } \\
\text { capacity. In the underground karst } \\
\text { system, the groundwater often has } \\
\text { the characteristics of large amount of } \\
\text { water and high pressure, and the } \\
\text { positive feedback of karst } \\
\text { development is strong }\end{array}$ & I \\
\hline $\begin{array}{c}\text { Medium } \\
\text { negative terrain }\end{array}$ & $\begin{array}{c}\text { The catchment capacity is the } \\
\text { second, and karst development } \\
\text { degree is the second }\end{array}$ & II \\
\hline $\begin{array}{c}\text { Small negative } \\
\text { terrain }\end{array}$ & $\begin{array}{c}\text { The capacity of water collection is } \\
\text { poor, and the development degree of } \\
\text { underground karst is generally poor }\end{array}$ & III \\
\hline No negative & $\begin{array}{c}\text { The intensity of groundwater activity } \\
\text { is low and generally speaking, the } \\
\text { ability of water and mud inrush to } \\
\text { cause disaster is very weak }\end{array}$ & IV \\
\hline
\end{tabular}

\subsubsection{The attitude of rock formation}

The development of rock dip is closely related to groundwater movement and karst development. The permeability of underground strata is anisotropic, and the permeability along the strata is much greater than that perpendicular to the strata. The flow pattern of groundwater, the degree of karst development and the distribution of karst water disasters are closely affected by 
the occurrence of rock strata. According to the analysis of statistical data, Li Liping ${ }^{[3-4]}$ thought that the most favorable attitude of rock stratum for karst development is the wing of syncline or anticline with dip angle of $25^{\circ}$ to $65^{\circ}$ and divides the dip angle of rock stratum into four levels, but the dip angle is not continuous after the classification. Zhou Zongqing ${ }^{[21]}$ and others corrected the dip angle of rock stratum, as shown in Table 5:

Table5. Relationships between strata inclination and risk grade of water inrush

\begin{tabular}{|c|c|c|}
\hline $\begin{array}{c}\text { dip angles of rock } \\
\text { stratum }\end{array}$ & $\begin{array}{c}\text { Correction value of } \\
\text { rock dip angle }\end{array}$ & $\begin{array}{c}\text { The level } \\
\text { of risk }\end{array}$ \\
\hline $\begin{array}{c}25^{\circ} \sim 5^{\circ}, 45^{\circ} \sim \\
65^{\circ}\end{array}$ & $25^{\circ} \sim 65^{\circ}$ & I \\
\hline $\begin{array}{c}25^{\circ}, 25^{\circ} \sim \\
80^{\circ}\end{array}$ & $10^{\circ} \sim 25^{\circ}$ & II \\
\hline $80^{\circ} \sim 90^{\circ}$ & $0^{\circ} \sim 10^{\circ}$ & III \\
\hline $0^{\circ} \sim 10^{\circ}$ & $0^{\circ} \sim 10^{\circ}$ & IV \\
\hline
\end{tabular}

\subsubsection{The level of surrounding rock}

The intact strength and mechanical properties of rock mass are closely related to the risk of water and mud inrush in tunnel. If the surrounding rock has good integrity, high strength and less harmful structural planes, it has strong deformation resistance and is not easy to cause water and mud inrush. The surrounding rock with poor integrity, low strength and more harmful structural planes has weak anti deformation ability, especially the weak zones (bodies) such as fault fracture zone and filling cavity often produce seepage instability or overall extrusion failure under the action of groundwater. If the construction is slightly improper, it can cause water and mud inrush and other disasters ${ }^{[3]}$. Hou Dongsai ${ }^{[23]}$ studied the relationship between rock mass integrity coefficient $\left(\mathrm{k}_{\mathrm{V}}\right)$, Poisson's ratio $(\mathrm{P})$ and risk level of water inrush, as shown in Table 6:

Table6. Relationships among integrity coefficient of rockmass, Poisson's ratio and grade of water inrush

\begin{tabular}{|c|c|c|}
\hline $\mathbf{K v}$ & $\mathbf{P}$ & The level of risk \\
\hline$<0.37$ & $<0.15$ & I \\
\hline $0.37-0.51$ & $0.1-0.25$ & II \\
\hline $0.50-0.74$ & $0.2-0.3$ & III \\
\hline$>0.74$ & $0.3-0.45$ & IV \\
\hline
\end{tabular}

\subsubsection{Rainfall}

Surface water is an important recharge source of groundwater. In rainy season or when there is heavy rainfall, the surface water is replenished, the water quantity rises rapidly, and the water quantity increases. At the grounding end of pipeline flow, the risk of water inrush in tunnel will increase. At the same time, the surface water will be collected into the karst cave or underground river through the seepage of cracks, which will recharge the groundwater and increase the probability of water inrush. According to the average annual rainfall, the precipitation intensity is divided into four levels, as shown in Table 7:

Table7. Relationships between average annual rainfall and risk grade of water inrush

\begin{tabular}{|c|c|}
\hline $\begin{array}{c}\text { the average annual } \\
\text { rainfall/mm }\end{array}$ & The level of risk \\
\hline$<400$ & I \\
\hline $400-800$ & II \\
\hline $800-1200$ & III \\
\hline$>1200$ & IV \\
\hline
\end{tabular}

\subsection{Comprehensive evaluation on the risk of water and mud inrush in tunnel}

According to the actual situation of the tunnel site and the summary of the influencing factors proposed in Section 2.1, the comprehensive evaluation table of the risk of water and mud inrush in the tunnel is obtained. The risk of the evaluation model is divided into four grades, and $\mathrm{S}$ is the corresponding expert rating. The criteria for determining different grades are shown in Table 8:

Table8. The factors and grading standard

\begin{tabular}{|c|c|c|c|c|c|}
\hline & \multirow[b]{2}{*}{$\begin{array}{l}\text { Influencing } \\
\text { factors }\end{array}$} & \multicolumn{4}{|c|}{ The level of risk } \\
\hline & & $\begin{array}{c}\mathrm{I} \\
(80 \leq \mathrm{S} \leq 100)\end{array}$ & $\begin{array}{c}\text { II } \\
(50 \leq \mathrm{S}<80)\end{array}$ & $\begin{array}{c}\text { III } \\
(20 \leq \mathrm{S}<50)\end{array}$ & $\begin{array}{c}\text { IV } \\
(0 \leq S<20)\end{array}$ \\
\hline \multirow{4}{*}{$\begin{array}{l}\text { Risk assessment } \\
\text { of water } \\
\text { and mud inrush } \\
\text { in Karst Tunnel } \\
\text { A }\end{array}$} & $\begin{array}{c}\text { Geological } \\
\text { structure } B_{1}\end{array}$ & $\begin{array}{l}\text { strong disaster } \\
\text { causing }\end{array}$ & $\begin{array}{l}\text { medium disaster } \\
\text { causing }\end{array}$ & $\begin{array}{l}\text { weak disaster } \\
\text { causing }\end{array}$ & $\begin{array}{l}\text { no disaster } \\
\text { causing }\end{array}$ \\
\hline & $\begin{array}{c}\text { Formation } \\
\text { lithology } \\
\mathrm{B}_{2} \\
\end{array}$ & strong soluble rock & $\begin{array}{l}\text { medium soluble } \\
\text { rock }\end{array}$ & $\begin{array}{l}\text { weak soluble } \\
\text { rock }\end{array}$ & No-soluble rock \\
\hline & $\begin{array}{c}\text { Groundwater } \\
\text { level } \mathrm{B}_{3}\end{array}$ & $\mathrm{~h} \geq 60 \mathrm{~m}$ & $30 \mathrm{~m} \leq \mathrm{h}<60 \mathrm{~m}$ & $0 \mathrm{~m} \leq \mathrm{h}<30 \mathrm{~m}$ & $\mathrm{~h}<0 \mathrm{~m}$ \\
\hline & $\begin{array}{l}\text { Geographic } \\
\text { and } \\
\text { geomorphic } \\
\text { conditions } \\
\mathrm{B}_{4}\end{array}$ & $\begin{array}{l}\text { large negative } \\
\quad \text { terrain }\end{array}$ & $\begin{array}{c}\text { medium negative } \\
\text { terrain }\end{array}$ & $\begin{array}{c}\text { small negative } \\
\text { terrain }\end{array}$ & $\begin{array}{l}\text { no negative } \\
\text { terrain }\end{array}$ \\
\hline
\end{tabular}




\begin{tabular}{|c|c|c|c|c|c|}
\hline & $\begin{array}{c}\text { The attitude } \\
\text { of rock } \\
\text { formation } \\
\mathrm{B} 5\end{array}$ & $25^{\circ} \sim 65^{\circ}$ & $10^{\circ} \sim 25^{\circ}$ & $0^{\circ} \sim 10^{\circ}$ & $0^{\circ} \sim 10^{\circ}$ \\
\cline { 2 - 5 } & $\begin{array}{c}\text { The level of } \\
\text { surrounding } \\
\text { rock B6 }\end{array}$ & $\begin{array}{c}\mathrm{Kv}<0.37 \\
\text { or } \mathrm{P}<0.15\end{array}$ & $\begin{array}{c}0.37 \leq \mathrm{Kv} \leq 0.51 \\
\text { or } 0.1 \leq \mathrm{P} \leq 0.25\end{array}$ & $\begin{array}{c}0.50 \leq \mathrm{Kv} \leq 0.74 \\
\text { or } 0.2 \leq \mathrm{P} \leq 0.3\end{array}$ & $\begin{array}{c}\mathrm{Kv}>0.74 \\
\text { or } 0.3 \leq \mathrm{P} \leq 0.45\end{array}$ \\
\hline $\begin{array}{c}\text { the average } \\
\text { annual rainfall } \\
\mathrm{B}_{7}\end{array}$ & $>1200 \mathrm{~mm}$ & $800 \mathrm{~mm}-1200 \mathrm{~mm}$ & $400 \mathrm{~mm}-800 \mathrm{~mm}$ & $<400 \mathrm{~mm}$ \\
\hline
\end{tabular}

\subsection{The weight analysis of influencing factors}

The weight analysis and risk assessment classification of risk factors for water inrush mud in karst tunnel are based on the analytic hierarchy process. Firstly, the judgment matrix $\mathrm{P}$ is constructed. Then, the factor weight vector $\omega$, the maximum eigenvalue $\lambda_{\max }$ and the random consistency ratio CR are calculated respectively by formula (1) - (4).

$$
\begin{aligned}
& \bar{\omega}=\left(\prod_{j=1}^{n} P_{i j}\right)^{1 / n} \quad(i=1,2, \ldots, n) \\
& \omega_{i}=\frac{\omega_{i}}{\sum_{j=1}^{n} \overline{w_{j}}} \quad(i=1,2, \ldots, n) \\
& \lambda_{\text {max }}=\left(\sum_{j=1}^{n}\left((A \omega)_{i} / \omega_{i}\right)\right) / n \\
& C R=\left\{\left(\lambda_{\text {max }}-n\right) /(n-1)\right\} / R I
\end{aligned}
$$

Where $A$ is the judgment matrix, $n$ is its order, $R I$ is the average random consistency index value of the judgment matrix, and for the 1-9 order judgment matrix, RI value is: $0,0,0.58,0.90,1.12,1.24,1.32,1.41,1.45$.

\subsubsection{Construct judgment matrix}

The judgment matrix represents the comparison of the relative importance between a certain factor at the upper level and its related factors at this level. Assuming that the

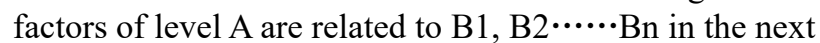
level, the judgment matrix is generally in the following form:

\begin{tabular}{|l|l|l|l|l|}
\hline $\mathrm{A}$ & $\mathrm{B}_{1}$ & $\mathrm{~B}_{2}$ & $\ldots \ldots$ & $\mathrm{B}_{\mathrm{n}}$ \\
\hline $\mathrm{B}_{1}$ & $\mathrm{~b}_{11}$ & $\mathrm{~b}_{12}$ & $\ldots \ldots$ & $\mathrm{b}_{1 \mathrm{n}}$ \\
\hline $\mathrm{B}_{2}$ & $\mathrm{~b}_{21}$ & $\mathrm{~b}_{22}$ & $\ldots \ldots$ & $\mathrm{b}_{2 \mathrm{n}}$ \\
\hline$\ldots \ldots$ & $\ldots \ldots$ & $\ldots \ldots$ & $\ldots \ldots$ & $\ldots \ldots$ \\
\hline $\mathrm{B}_{\mathrm{n}}$ & $\mathrm{b}_{31}$ & $\mathrm{~b}_{\mathrm{n} 2}$ & $\ldots \ldots$ & $\mathrm{b}_{\mathrm{nn}}$ \\
\hline
\end{tabular}

$b_{11}, \cdots \cdots, b_{n n}$ is the relative importance of each evaluation factor, which can be determined by the 1-9

\begin{tabular}{|c|c|}
\hline $\begin{array}{l}\text { Intensity of } \\
\text { Importance }\end{array}$ & sense \\
\hline 1 & $\begin{array}{l}\text { It means that two factors are equally } \\
\text { important }\end{array}$ \\
\hline 3 & $\begin{array}{l}\text { One factor is moderately more } \\
\text { important than the other }\end{array}$ \\
\hline 5 & $\begin{array}{l}\text { One factor is strongly more important } \\
\text { than the other }\end{array}$ \\
\hline 7 & $\begin{array}{l}\text { One factor is very strongly more } \\
\text { important than the other }\end{array}$ \\
\hline 9 & $\begin{array}{l}\text { One factor is extremely strongly more } \\
\text { important than the other }\end{array}$ \\
\hline $2,4,6,8$ & $\begin{array}{l}\text { The median value of the above adjacent } \\
\text { judgment }\end{array}$ \\
\hline $\begin{array}{l}\text { Reciprocal of } \\
\text { above }\end{array}$ & $\begin{array}{l}\text { If } b_{i j} \text { is obtained by comparing factor } i \\
\text { with } j \text {, then } b_{i j}=1 / b_{i j} \text { by comparing } \\
\text { factor } j \text { with } i\end{array}$ \\
\hline
\end{tabular}
scale method (Table 9) ${ }^{[20]}$, and through the comparison between the two factors, the value is determined.
Table9. The significance of 1-9 scale

\subsubsection{Weight analysis of each influencing factor}

Based on the statistics of engineering examples and theoretical analysis, and referring to the existing research results, the risk evaluation matrix of water and mud inrush in karst tunnels is constructed:

$\mathrm{P}_{\mathrm{A}-\mathrm{B}}=\left[\begin{array}{lcccccc}1 & 2 & 2 & 4 & 6 & 7 & 7 \\ 1 / 2 & 1 & 1 & 2 & 3 & 4 & 4 \\ 1 / 2 & 1 & 1 & 2 & 3 & 4 & 4 \\ 1 / 4 & 1 / 2 & 1 / 2 & 1 & 2 & 3 & 3 \\ 1 / 6 & 1 / 3 & 1 / 3 & 1 / 2 & 1 & 2 & 2 \\ 1 / 7 & 1 / 4 & 1 / 4 & 1 / 3 & 1 / 2 & 1 & 1 \\ 1 / 7 & 1 / 4 & 1 / 4 & 1 / 3 & 1 / 2 & 1 & 1\end{array}\right]$

According to formula (1) - (4), the matrix weight vector $\omega_{\mathrm{A}-\mathrm{B}}=[0.364,0.189,0.189,0.111,0.062,0.043$, 0.043 ], the maximum eigenvalue $\lambda \max =7.061$, the consistency index $\mathrm{CI}=0.010, \mathrm{C}_{\mathrm{r}}=0.008<0.1$, which meets the consistency condition. From the calculation results, it can be seen that geological structure, formation lithology and groundwater level have the greatest influence on water inrush, and the sum of weights accounts for $73.7 \%$ of all factors, followed by geographic 
and geomorphic conditions and the attitude of rock formation, with the sum of weights accounting for $17.7 \%$ of all factors, and finally the level of surrounding rock and rainfall, with the sum of weights accounting for $8.6 \%$ of all factors.

\section{Risk assessment of water or mud inrush of a tunnel in Chongqing}

\subsection{Risk assessment}

A tunnel in Chongqing is a separate and independent twohole tunnel. The left tunnel is $7635.00 \mathrm{~m}$ long and the right tunnel is $7656.00 \mathrm{~m}$ long. The maximum buried depth is $1296.50 \mathrm{~m}$. It is a deep buried extra long mountain tunnel. The tunnel site belongs to the high and middle mountain landform of structural dissolution erosion, and there are three faults, four anticlines and three synclines in the area, with strong tectonic compression and broken rock mass. The strata through the tunnel are composed of the lower Triassic Jialingjiang Formation, Daye Formation, Permian, Silurian and Ordovician strata. The lithology is mainly composed of limestone, shale, siltstone and so on. The rocks are soft rock $\sim$ hard rock, and The level of surrounding rocks are $\mathrm{V} \sim$ III. The groundwater in the tunnel site is mainly carbonate rock fissured karst water and fissured karst water. Due to the uneven development of karst, the distribution and enrichment of groundwater are also uneven. Therefore, concentrated water gushing may occur in the local karst pipeline development area during construction.

Therefore, the stratum lithology and geological structure of the tunnel are complex, and the tunnel body mainly passes through the soluble rock section. There are rich water and ponding in the fault, the contact zone between soluble rock and non soluble rock, and the syncline core where the tunnel site is located. During the tunnel construction, the probability of encountering large karst caves, underground rivers, dissolution funnels and other hidden karst forms is high, which is very easy to induce water and mud inrush in the tunnel. Therefore, it is necessary to strengthen the prediction of water and mud inrush disaster and take measures in advance to ensure the construction safety.

The tunnel is divided into four sections according to the mileage pile number, and the influencing factors of water and mud inrush risk in each section are analyzed and evaluated respectively, as shown in Table 10.

Table10. Evaluation index analysis of each section

\begin{tabular}{|c|c|c|c|c|c|c|c|}
\hline & $\begin{array}{c}\text { Geological } \\
\text { structure B1 }\end{array}$ & $\begin{array}{c}\text { Formation } \\
\text { lithology B2 }\end{array}$ & $\begin{array}{c}\text { Groundwater } \\
\text { level } \\
\mathrm{B} 3\end{array}$ & $\begin{array}{c}\text { Geographic and } \\
\text { geomorphic } \\
\text { conditions B4 }\end{array}$ & $\begin{array}{c}\text { The attitude } \\
\text { of rock } \\
\text { formation } \\
\mathrm{B} 5\end{array}$ & $\begin{array}{c}\text { The level of } \\
\text { surrounding } \\
\text { rock B6 }\end{array}$ & $\begin{array}{c}\text { the } \\
\text { average } \\
\text { annual } \\
\text { rainfall B7 }\end{array}$ \\
\hline $\begin{array}{c}\mathrm{K} 46+495 \sim \\
\mathrm{K} 50+300\end{array}$ & $\begin{array}{c}\text { strong } \\
\text { disaster } \\
\text { causing }\end{array}$ & $\begin{array}{c}\text { strong } \\
\text { soluble rock }\end{array}$ & $\mathrm{h} \geq 60 \mathrm{~m}$ & $\begin{array}{c}\text { large negative } \\
\text { terrain }\end{array}$ & $35^{\circ} \sim 60^{\circ}$ & $\begin{array}{c}\mathrm{Kv}=0.30 \\
\mathrm{P}=0.25\end{array}$ & $1261.4 \mathrm{~mm}$ \\
\hline $\begin{array}{c}\mathrm{K} 50+300 \sim \\
\mathrm{K} 53+050\end{array}$ & $\begin{array}{c}\text { strong } \\
\text { disaster } \\
\text { causing }\end{array}$ & $\begin{array}{c}\text { strong } \\
\text { soluble rock }\end{array}$ & $\mathrm{h} \geq 60 \mathrm{~m}$ & $\begin{array}{c}\text { large negative } \\
\text { terrain }\end{array}$ & $25^{\circ} \sim 77^{\circ}$ & $\begin{array}{c}\mathrm{Kv}=0.30 \\
\mathrm{P}=0.25\end{array}$ & $1261.4 \mathrm{~mm}$ \\
\hline $\begin{array}{c}\mathrm{K} 53+050 \sim \\
\mathrm{K} 53+725\end{array}$ & $\begin{array}{c}\text { diseak } \\
\text { dister }\end{array}$ & $\begin{array}{c}\text { weak } \\
\text { soluble rock }\end{array}$ & $30 \mathrm{~m} \leq \mathrm{h}<60 \mathrm{~m}$ & $\begin{array}{c}\text { medium } \\
\text { negative terrain }\end{array}$ & $35^{\circ} \sim 45^{\circ}$ & $\begin{array}{c}\mathrm{Kv}=0.64 \\
\mathrm{P}=0.3\end{array}$ & $1261.4 \mathrm{~mm}$ \\
\hline $\begin{array}{c}\mathrm{K} 53+725 \sim \\
\mathrm{K} 54+150\end{array}$ & $\begin{array}{c}\text { strong } \\
\text { disaster } \\
\text { causing }\end{array}$ & $\begin{array}{c}\text { medium } \\
\text { soluble rock }\end{array}$ & $30 \mathrm{~m} \leq \mathrm{h}<60 \mathrm{~m}$ & $\begin{array}{c}\text { large negative } \\
\text { terrain }\end{array}$ & $35^{\circ} \sim 68^{\circ}$ & $\begin{array}{c}\mathrm{Kv}=0.5 \\
\mathrm{P}=0.21\end{array}$ & $1261.4 \mathrm{~mm}$ \\
\hline
\end{tabular}

The risk classification of water and mud inrush in tunnel can be obtained by summation of the product of expert score and factor weight (formula 6). The form of score vector is shown in formula (5):

$$
\begin{gathered}
F=\left[\begin{array}{llll}
f_{1} f_{2} & \ldots f_{i} & \ldots f_{n}
\end{array}\right] \\
S=F \cdot w
\end{gathered}
$$

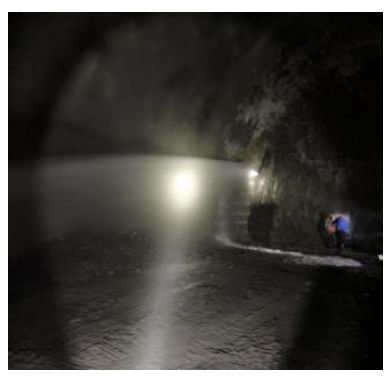

Fig. 1. Side gushing water

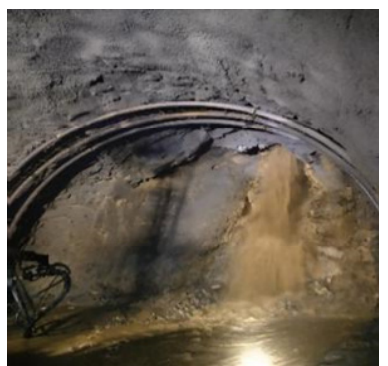

Fig. 2. Muddy water gushes from top 


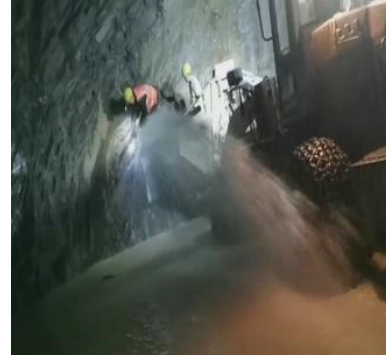

Fig. 3. A lot of muddy water

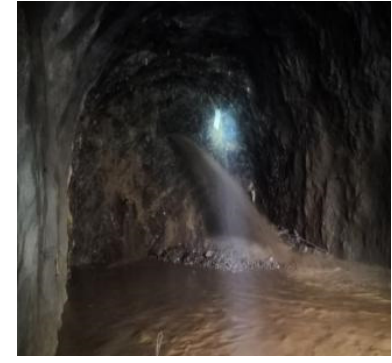

Fig. 4. Water gushes out of the excavation face

\subsection{The validation}

There are many water and mud inrush accidents of different scales occurred (Fig.1 Fig.4) during the excavation and construction of the tunnel. For example, when the tunnel was repaired to $\mathrm{K} 48+340-\mathrm{K} 48+352.8$, mud inrush and water inrush occurred at the arch waist on the right side of the tunnel entrance, with a square amount of about $400 \mathrm{~m}^{3}$. After that, mud inrush occurred again, resulting in extrusion deformation of I-beam and water inrush with pressure. When the construction length of the hand face is $\mathrm{K} 48+617$, there is water seepage in the deepened gun hole of the left vault, and the water pressure is small. When the construction reaches YK48+622, there is water gushing in the left vault, the aperture is about 0.5 0.7 meters, and the water inflow is $3000 \mathrm{~m}^{3} / \mathrm{h}$. When the face of the hand is excavated to K51+081, water gushing appears in the left hole of the exit. The jet distance is as long as $30 \mathrm{~m}$, and the water inflow reaches $410 \mathrm{~m}^{3} / \mathrm{h}$. Many water and mud inrush accidents occurred during inclined shaft construction. The evaluation results of water and mud inrush in tunnel are in good agreement with the field excavation results, which verifies the rationality and feasibility of the risk evaluation method of water and mud inrush in tunnel based on hierarchical method.

\section{Conclusion}

(1) Based on statistics and analytic hierarchy process (AHP), the influencing factors and factor weights of water and mud inrush in karst tunnel are analyzed. The results show that the main controlling factors of water and mud inrush are geological structure, formation lithology and groundwater level; geographic and geomorphic conditions, attitude of rock formation are the minor significant factors, surrounding rock mass classification, rainfall are the least important elements.

(2) The risk of water inrush and mud inrush can be quantified by the product of expert score and factor weight, which can be used to grade the risk of water inrush in karst tunnels under different hydrogeological conditions or in different sections of karst tunnels.

(3) The risk assessment method proposed in this paper is used to evaluate and classify the risk of water and mud inrush in each section of a tunnel in Chongqing, and the evaluation results are consistent with the actual excavation situation. Therefore, this method can provide a theoretical basis for the project design and construction organization 
design of the tunnel to reduce the risk of water and mud inrush.

\section{References}

1. Li Shu-cai, Xu Zhen-hao, Huang Xin, et al.CHIN J ROCK MECH ENG, 37 (5), 1041-1069(2018)

2. Hou Dongsai, Zhang Xiao, Wang Lei. TUNNEL CONSTR, 37(6), 691-699(2017)

3. Xu Zhenhao, Li Shucai, Li Liping,et al. ROCK SOIL MECH, 32(6), 1757-1765(2011)

4. Li Liping, Li Shucai, Chen Jun, et al. CHIN J ROCK MECH ENG, 30(7), 1345-1354(2011)

5. Zhou Zong-qing, Li Shu-cai, Li Li-ping, et al. ROCK SOIL MECH, 34(3), 818-826(2013)

6. Li Shucai, Zhou Zongqing, Li Liping, et al.CHIN J ROCK MECH ENG, 32(9), 1858-1867(2013)

7. Mao Bang-yan, Xu Mo, Jiang Liang-wen. CARSOL SIN, 29(2), 183-189(2010)

8. Han Xing-rui. CARSOL SIN, 23(3),213-218(2004)

9. Du Yu-chao, Han Xing-rui, Li Zhao-lin.CARSOL SIN, 28(3), 281-287(2009)

10. Zhang Qing-song, Li Shu-cai, Han Hong-wei, et al.J SHANDONG UNIV (ENG SCI), 39(3), 106 110(2009)

11. Kuang Xing, Bai Ming-zhou, Wang Cheng-liang, et al. J HIGHW TRANSP RES DEV, 27(11), $100-$ 103(2010)

12. Yang Zhuo, Ma Chao. TUNNEL CONSTR, 36 (11), 1337-1342(2016)

13. Zeng Zhifa, Song Bo, Li Tianbin, et al. J CHINA FOREIGN HIGHW, 31(4), 213-216(2011)

14. Jiang Guoyun.CHIN J UNDERGROUND SPACE ENG, 8 (2), 274-279(2012)

15. Shu Sen.RAILW STANDARD DESIGN, 59(4), $72-$ 78(2015)

16. Mao Zhengjun, Yang Shaozhan, Zhu Yanyan, et al.J RAILW SCI ENG, 14 (6), 1332-1339(2017)

17. Liu Dongbo.RAILW CONSTR TECHNOL, 08, 36$39+69(2018)$

18. Yang Yanna, Cao Huaping, Xu Mo. GEOSCI, 29(2), 414-420(2015)

19. Wang Deming. SHANDONG UNIV(2017)

20. SAATY T L. EUR I OPER RES, 48(1), 9-26(1990) 